\title{
Strategy to Increase Sugar Production at PT. Perkebunan Nusantara (PTPN) XIV Takalar Sugar Factory
}

\author{
A. Irga Satrawati Taslim', Didi Rukmana², Rahmadanih² \\ ${ }^{1}$ Agribusiness Study Program Students, Postgraduate School of Hasanuddin University \\ ${ }^{2}$ Lecturer of Agribusiness Program, Postgraduate School of Hasanuddin University \\ ${ }^{3}$ Lecturer of Managemen Department of Hasanuddin University \\ * Corresponding author: \\ Email : irgasatrawati@gmail.com
}

\begin{abstract}
.
This study aims to formulate priority strategies to increase the production of sugar is right for PTPN XIV PG. Takalar. This research uses qualitative and quantitative approaches. The research was conducted by distributing questionnaires and indepth interviews to informants. Then the data were analyzed by using Analysis Hierarchy Process. The results of this study indicate factors that affect the strategy of enhacement production of sugar in PTPN XIV PG. Takalar is the potential for a broad area of planting sugar cane, machine factories were already old, the increase in demand for sugar, and the disputed land. The priority order of the strategy is the first to utilize the land potential and factory capacity as well as the development of plant cultivation technology to improve the quality and yield of sugar with a weight of AHP value (0.150). On Priority two is optimalisasi utilization of land and the capacity of the plant by weighting the value of AHP (0.112). On Priority three is maximizing spacious land with the utilization of the development of technology of cultivation of plants with value weights AHP (0.098). On Priority, fourth is coordination between the authorities and the factory with value weights AHP (0.095). On Priority Fifth is utilization infrastructure marketing with value weights AHP (0.089). At priority, sixth is to strive to repair or renewal the machine factory with value weights AHP (0.051).
\end{abstract}

Keywords: Factory Sugar, Strategy, Increase Production

\section{INTRODUCTION}

The development of the plantation sub- sector as part of the development of the agricultural sector and national development is one of the important potentials in efforts to improve people's welfare. The role of strategic sub- sector of plantation in improving the economy nationwide is illustrated by its contribution in the various terms of one of them as a contributor to the Product Domestic Bruto (GDP). One of the 
commodity plantations are preferred as consumption in the country is the cane to the production of Sugar Crystal White [1].

Sugar is one of the ingredients of goods, items concerning the livelihood of life of people much to scale the fulfillment needs are high and menjadin factors supporting the welfare of the community, a source of calories for people other than rice maize and Numbi Crops [2]. To meet the needs of the population that is around 260 million inhabitants, the needs of sugar in Indonesia is the average growth of $4 \%$ every year. Domestic sugar consumption in 2017 is projected to reach 5.1 million tons while production is only 2.5 million tons. As a result the sugar balance experienced a deficit of 2.6 million tons. In the year 2018 the consumption of 5.1 million tons while production of 2.4 million tons thus experiencing a deficit of 2.6 million tons. In the year 2019 the consumption of sugar 5.1 million tons while production of 2.5 million tons thus experiencing a deficit of 2.7 million tons [3] .

When this sugar as one of the ingredients of goods are still imported from other countries because production in the country still have not been able to meet and balance the demands of society. The way this is not a solution that is appropriate to address the lack of fulfillment of the needs of the community will be sugar. How the best is stabilizing the production of sugar in the country, in addition to save foreign exchange in the country as a result of reduced imports of sugar, sales of sugar in the country was to be increased. The existence of a sugar factory in an effort to increase sugar production is believed to be able to make a major contribution to meeting national sugar needs. Factory sugar has a role which is very important in producing sugar because it is where the course of the processing of sugar cane into sugar .

PTPN XIV PG. Takalar is one of the factories of sugar are still active in the efforts to fulfill the needs of sugar in particular to South Sulawesi. PG. Takalar located in the village of Pa'rappunganta, District of Polombangkeng North District Takalar, Province of South Sulawesi. PG. Takalar was established in order to implement government policies for national sugar self-sufficiency based on the Decree of the Minister of Agriculture 40 RI Number 668/Kpts/Org/8/1981 dated 11 August 1981. PG. Takalar has a capacity of milling 3,000 tons of cane per day (TTH) and the vast acreage planted sugarcane $\pm 6000 \mathrm{Ha}$.

Based on the description at the top of the researchers interested to know the activities of procurement of materials raw, processing and marketing of the PG. Takalar to establish an alternative strategy that is appropriate to do in increasing the production of sugar. So the researchers conducted research with the title "Strategy to Increase Sugar Production at PT. Perkebunan Nusantara (PTPN) XIV Takalar Sugar Factory". 


\section{METHODS}

This research uses qualitative and quantitative approaches . Qualitative with a focus on the analysis of preparing alternative strategies in $p$ e enhancing the production of sugar. the purpose of the research qualitative is to understand a context to describe in detail about the condition of what are actually happening in the field [4]. A quantitative approach to analyze the priority scale of problems that occur in PTPN XIV PG. Takalar were obtained from each informant. While for the source of the data can be classified into two, namely primary and secondary. Primary data is in the form of observations by researchers and results of interviews with key informants. Informants key is they who provide information in a clear and reliable associated with the information that wants to be obtained [5]. Data Secondary obtained in the form of data written in the office camat and various literature more that comes from the journal of scientific, the Indonesian Central Statistics Agency, books, and others are related to the research. AHP is a model of support decisions that were developed by Thomas L. Saaty. Models supporting the decision is going to decipher the problem some factor or multi- criteria that complex into a hierarchy [6]. The principle of work AHP is to simplify a problem complex that is not structured, strategic and dynamic into its parts, and arrange in a hierarchy. Then the level of interest of each of the variables that are relatively compared with the variable to another. From the various considerations that then do the synthesis to define the variables that have a priority higher and contribute to influence the outcome in a system that [7] .

Excess AHP is able to provide a framework that is comprehensive and rational in structuring problems making decisions, while the weakness of AHP is the dependence of the AHP model with inputs and the method is only a method of mathematical without no testing is systematic. Data analysis used the Expert Choice computer program [8].

Step build a hierarchy that starts with the objectives, criteria, and alternative actions. Hierarchy is a structural abstraction of a system that studies the interaction function between components and their impact on a system. This stage builds a hierarchy starting with alternative goals, criteria, and actions. Hierarchy is a structural abstraction of a system to study the function of the interaction between components and their impact on a system. 
Goal

Criteria

Alternative

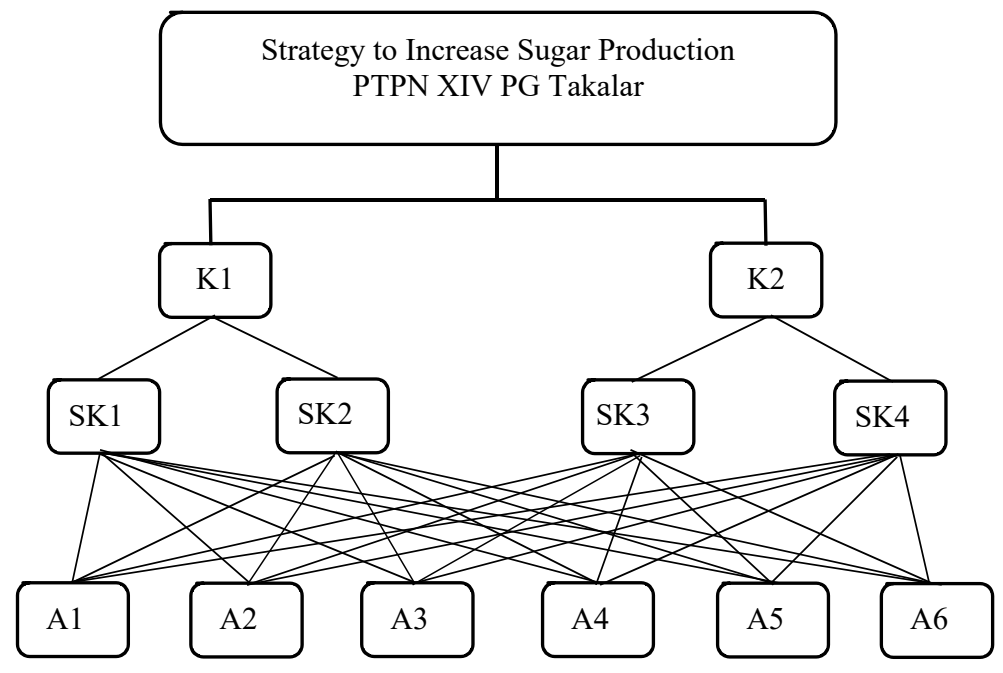

Fig 1. Hierarchical Structure

Information :

$\mathrm{K}$ : Criteria, things that become a factor target .

SK : Sub-criteria, the things that become part of the criteria .

A : Alternative, things that have been formulated as options to be recommended as a result to achieve research objectives .

This stage builds a hierarchy starting with alternative goals, criteria, and actions. Hierarchy is a structural abstraction of a system to study the function of the interaction between components and their impact on a system [9] .

\section{Table 1 : Pairwise Appeal Scale Values in AHP}

\begin{tabular}{cll}
\hline $\begin{array}{c}\text { Intensity of } \\
\text { Importance }\end{array}$ & \multicolumn{1}{c}{ Defenition } & \multicolumn{1}{c}{ Explanation } \\
\hline $\mathbf{1}$ & Equal importance & $\begin{array}{l}\text { Two activities contribute equally to the } \\
\text { objective }\end{array}$ \\
\hline $\mathbf{3}$ & Moderate more importance & $\begin{array}{l}\text { Experience and judgment strongly favor } \\
\text { one activity over another }\end{array}$ \\
\hline $\mathbf{5}$ & $\begin{array}{l}\text { Essensial, Strong more } \\
\text { importance }\end{array}$ & $\begin{array}{l}\text { Experience and judgment strongly favor } \\
\text { one activity over another }\end{array}$ \\
\hline $\mathbf{9}$ & Demonstrated importance & $\begin{array}{l}\text { An activity is strongly favored and its } \\
\text { dominance demonstrated in practice. }\end{array}$ \\
\hline $\mathbf{2 , 4 , 6 , 8}$ & Absolutely more importance & $\begin{array}{l}\text { The evidence favoring one activity over } \\
\text { another is of the highest possible order of } \\
\text { affirmation }\end{array}$ \\
\hline & Inverse & opposite value when compared to i. \\
\hline Source : Saaty, 1983 . & When compromise is needed \\
\hline
\end{tabular}


To quantify the qualitative data, a Pairwise Comparison Scale is used. The numerical value applied to all comparisons is obtained from the ratio scale 1 to 9 determined by Saaty, as in Table 1 above, a decision maker will provide an assessment, perceive or predict the likelihood of a thing or event being encountered. The assessment will be formed into a matrix of pairs at each level of the hierarchy [10] .

\section{RESULT AND DISCUSSION}

Informants in the study it was 7 who is Head of the Section of Plant, Sinder Gardens Region, Head Cutting and Transports, Assistant Chemicker, Machinist, Head of Section Installation, Assistant Finance at PTPN XIV PG. Takalar . The determination of informants was carried out deliberately with several considerations in order to produce the right strategic priorities. AHP model uses human perception which is considered by experts as its main input. By because it is, the selection of informants should be highly considered .

\section{Hierarchical Tree Structure}

Research is a structural hierarchy of four levels, where the hierarchy level of the first is a destination that wants to be achieved by the decision on the strategy of development of agro-industries in PTPN XIV PG. Takalar . In the hierarchy level of both constituted by four groups of factors such as that defined that factors internal and external . In the hierarchy level of the third is subfactors are constituted by factors are included in each of the four groups of level before and hierarchical level of the fourth is an alternative strategy based on the strategy that should be evaluated and compared.

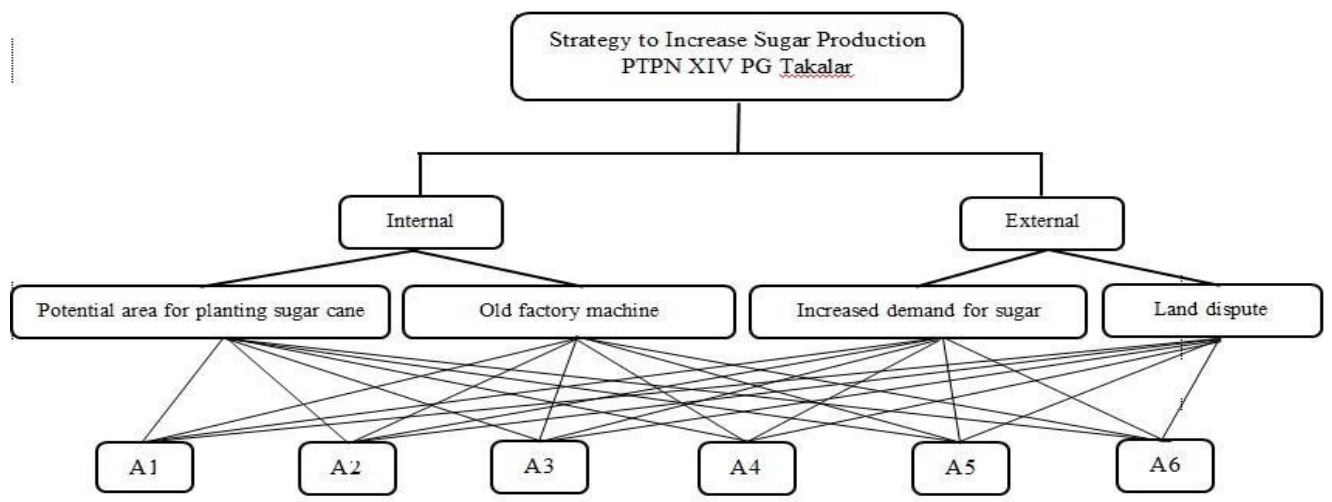

Fig 2 . Hierarchical Structure of Strategy to Increase Sugar Production of PTPN XIV PG. Takalar

Information :

A1 Utilization of marketing infrastructure.

A2 Attempt to repair or update factory machines.

A3 Utilizing land potential and factory production capacity as well as developing 
plant cultivation technology.

A4 coordination between the authorities and the factory.

A5 Perform simple irrigation (water supply) on dry land.

A6 Increase the availability of facilities and infrastructure tool unloading freight cane that efficient.

Table 2 : Results of Processing By Horizontal inter Element Factor

\begin{tabular}{cllc}
\hline \hline \multicolumn{1}{c}{ Criteria } & \multicolumn{1}{c}{ Sub Criteria } & AHP & Priority \\
\hline \multirow{2}{*}{ Internal } & Potential spacious area planting sugarcane & 0.389 & 3 \\
& Machinery plant that is already old & 0.493 & 1 \\
\hline \multirow{2}{*}{ External } & Increased demand for sugar & 0.311 & 4 \\
& Disputed land & 0.391 & 2 \\
\hline \hline
\end{tabular}

Source: Primary Data After Processing, 2020.

Hacyl processing is horizontally between elements of the hierarchy is the order of sub-criteria based on factors which influence the process of the increase of production in PTPN XIV PG. Takalar is as follows .

Priority subcriteria first is a machine factory that is already old by weight AHP (0.493). Hours stop grinding on PG. Takalar dominated by the clock stop B, where the clock stops B is the termination of activity of milling cane as a result of the factory among others due to full tanks holding sap, replacement or maintenance of equipment factories were damaged or wear out [11] . At the moment the process of milling at PG. Takalar ordinary happened bottlenecks so that all the activities of the factory stopped terms of the ordinary happens because due to the age of the plant that is already old so some of the equipment that exist in the plant is not functioning optimally.

The second sub-criteria priority is the existence of land disputes between residents around the factory with a weight of AHP (0.391). Disputed land that occurred between the PG. Takalar and citizens around factories that where the factory claimed land hers have a certificate that is valid while the residents also claimed things are the same. It is able to lead the process of development effort at PG. Takalar is blocked.

Priority subcriteria third is the potential for broad area of planting cane with weights AHP (0389). In essentially broad area that is managed by PTPN XIV PG. Takalar very influential on the activities of farming and the production of sugar which will be produced. The total area of land that is owned by PG. Takalar is $\pm 6000 \mathrm{Ha}$ and the realization is around $\pm 4000 \mathrm{Ha}$. If the land that can be realized as a whole it is very influential on the amount of supply of material raw sugar cane and sugar which will be produced and can provide results that maximum .

The fourth sub-criteria priority is an increase in demand for sugar with a weight of AHP (0.311). The growth of the population that continues to increase from year to year caused demand to sugar continues to rise . Consumption of sugar national per capita amounted to $17 \mathrm{~kg}$ per year while the supply of sugar locally only able to meet more than $50 \%$ consumption of sugar nationwide. While the production in the 
country is smaller than its consumption . For example, only the production of sugar nationwide in 2007 approximately 2.3 million tons/year, with details of factory sugarowned SOE 1.6 million tons per year and plant sugar -owned private 0.7 million tons per year, while consumption is national about 4 million tons per year. In the year 2009 , the production of local reach 2.5 million tons , while total consumption is 4.8 million tons, with details of the consumption of sugar the public in the country of 3 million tons and consumption industries which reached 1.8 million tons. Until now , the annual sugar demand data has reached around 4 to 4.8 million tons per year for both public and industrial consumption.

Table 3 . AHP results from the combination of all informants

\begin{tabular}{|c|c|c|c|c|c|c|}
\hline \multirow[t]{2}{*}{ Alternative } & \multicolumn{4}{|c|}{ Criteria } & \multirow[t]{2}{*}{ Average } & \multirow[t]{2}{*}{ Priority } \\
\hline & 1 & 2 & 3 & 4 & & \\
\hline $\begin{array}{l}\text { Utilization of marketing } \\
\text { infrastructure }\end{array}$ & 0.085 & 0.055 & 0.140 & 0.077 & 0.089 & 4 \\
\hline $\begin{array}{l}\text { Attempt to repair or update } \\
\text { factory machines }\end{array}$ & 0.066 & 0.175 & 0.136 & 0.042 & 0.051 & 6 \\
\hline $\begin{array}{l}\text { Utilizing the potential of land and } \\
\text { factory production capacity as } \\
\text { well as developing plant } \\
\text { cultivation technology }\end{array}$ & 0.174 & 0.140 & 0.159 & 0.130 & 0.150 & 1 \\
\hline $\begin{array}{l}\text { Coordinating between the } \\
\text { National Land Agency (BPN) } \\
\text { and the factory }\end{array}$ & 0.057 & 0.060 & 0.048 & 0.150 & 0.095 & 3 \\
\hline $\begin{array}{l}\text { Perform simple irrigation (water } \\
\text { supply) on dry land }\end{array}$ & 0.076 & 0.070 & 0.107 & 0.130 & 0.096 & 2 \\
\hline $\begin{array}{l}\text { Increase the availability of } \\
\text { facilities and infrastructure tool } \\
\text { unloading freight cane that } \\
\text { efficient }\end{array}$ & 0.075 & 0.077 & 0.059 & 0.062 & 0.068 & 5 \\
\hline
\end{tabular}

Source: Primary Data After Processing, 2020.

The results of processing weight and priority order of alternative strategies to increase sugar production at PTPN XIV PG. Takalar is done by calculating the average based on criteria points. The order of priority strategies is as follows.

The priority of the first alternative strategy is to exploit land potential, factory capacity and development of plant cultivation technology with a weight of AHP value (0.150). Exploiting the potential of land sugarcane that exist in PG. Takalar need immediately realized that before $\pm 4000 \mathrm{Ha}$ become $\pm 6000 \mathrm{Ha}$. In addition it is to improve the quality and results of the production of sugar need to do the development of technology of cultivation of plants such as the processing of land that is fertile , planting varieties of seeds of superior, fertilizing the right, the system of irrigation 
that is good and protection from pests and diseases in order to quality that is expected to be achieved, namely the yield of sugar that high . To improve the results of the production can be done by maximizing the capacity of mill rollers which previously 3.000 TCD become 4.000 TCD.

The second priority alternative strategy is to perform simple irrigation on dry land with a weighted AHP value (0.096). In the vegetative phase, sugarcane lacks water while lebung-lebung is a source of water for PG. Takalar not sufficient to irrigate the entire land, then of the parties PG. Takalar need to do setting the source power of water in canal irrigation in order to meet the needs of aquaculture. Things are done to accommodate water rain or flow surface on where the shelter temporarily or shelter permanently to be used to irrigate crops . By because it's, harvesting water in addition to work to provide water irrigation on a summer drought, and technology is beneficial for the area of land that does not have a network of irrigation or a source of water under the surface (water land).

The third priority alternative strategy is coordination between the authorities and the factory with a weighted value of AHP (0.095). Disputed land that occur between the factory and residents from around the plant, it certainly can hamper the process of production becomes not maximum, then from the party factories need to coordinate the authorities in terms of these parties Agency Land (BPN) and government local to address the matter of the order the process of procurement of materials raw from the land to the process of production can be run with smooth.

The fourth alternative priority is the use of marketing infrastructure with a weighted value of AHP (0.089). With the utilization of infrastructure marketing that is centered in the office of the Board of Directors of PTPN XIV Makassar is in the form of staff marketing who care system information the price of sugar, transaction sale and purchase to the delivery of goods in the form of sugar to place the buyer, as well as support the policy of government, in terms of this Kepmerindag No. 230 / MPP / Kep / 6/1999, regarding the lifting of Kepmerindag No. 363 / MPP / Kep / 8/1999 concerning the trading system of import sugar with the purpose of imposing tariffs of import of sugar by $20 \%$ for raw sugar and $25 \%$ of white sugar to protect industry in the country. Furthermore, Kepmerindag No. 643 / MPP / Kep / 9/2002, 23 september 2002 , concerning trading system imported sugar which aims to restrict the perpetrator of imported sugar and the volume of imports of sugar, is expected to process marketing PG. Takalar can be fulfilled [12] .

Priorities alternative strategy fifth is increasing the availability of facilities and infrastructure tool unloading freight cane which efficiently by weighting the value of AHP (0.068). The low supply of sugar cane that is entered into the factory resulted in delays in the process of production, one of which caused by the lack of means of unloading the transport of sugar cane in the form of a grab loader and excavator. By because it is the PG. Takalar need to increase the number of appliance load haul cane with a way to add or hire. 
The sixth priority alternative strategy is to seek repair or renewal of factory machines with AHP weight value (0.051). The high demand for sugar is an opportunity that must be achieved by PG. Takalar as one of the process to develop the business . It is necessary to do to carry out maintenance and repair machinery production are already parents are routine in order to keep optimum production .

\section{CONCLUSION}

Based on the results of AHP analysis, it shows that the main subcriteia that affects the strategy to increase sugar production at PTPN XIV PG. Takalar is the potential for broad area of planting sugar cane (0.493). Subcriteria second is a machine factory that is already old (0.391). The third sub-criteria is an increase in demand for sugar $(0.389)$. The fourth sub-criteria priority is land disputes $(0.311)$ and the main priority of alternative strategies to increase sugar production at PTPN XIV PG. Takalar is to utilize the potential of land and factory capacity as well as the development of plant cultivation technology to increase the quality and yield of sugar production (0.150).

\section{ACKNOWLEDGMENTS}

The authors are grateful to all parties who have contributed to this research, so that this research can be carried out properly.

\section{REFERENCES}

[1] Badan Pusat Statistik, Indonesian Sugar Cane Statis. 2019.

[2] Peraturan Presiden Nomor 71, "Peraturan Presiden Nomor 71 Tahun 2015," vol. 151, pp. 10-17, 2015, doi: 10.1145/3132847.3132886.

[3] R. Indah Kurniasari, Dwidjono Hadi Darwanto, dan Sri Widodo, "Permintaan Gula Kristal Mentah Indonesia," Ilmu Pertan. (Agricultural Sci., vol. 18, no. 1, p. 24, 2015, doi: 10.22146/ipas.6173.

[4] Erika Dwi Alviana, "Pendekatan Kualitatif," Pemikir. Masy. Ilm. Berwawasan Agribisnis, vol. 5, no. 2, pp. 156-164, 2019.

[5] H. Khoisah, "Penentuan Informan Kunci," Вестник Росздравнадзора, vol. 6, no. 2, pp. 5-9, 2017.

[6] Andi Supriadi chan, "Menentukan nilai prioritas dengan metode analytical hierarchy process untuk menentukan kualitas kayu manis pada bahan arang sebagai alternatif pengganti minyak tanah," vol. 3, no. 2, pp. 133-147, 2015.

[7] L. Sutiarso, "Aplikasi Analytical Hierarchy Process (AHP) untuk Penentuan Strategi Pengembangan Subak," Agritech, vol. 31, no. 2, pp. 138-145, 2012, doi: 10.22146/agritech.9737.

[8] F. Retnoningsi, "Pemilihan Prioritas Strategi Pemasaran Coklat Olahan Berdasarkan Metode Analytical Hierarchy Process," p. 634.

[9] Hartono, "Pemanfaatan Metode Analytical Hierarchy Process Untuk Penentuan Jenis Barang Yang Akan Di Produksi," J. Media Infotama, Vol.9, No.1, Februari 2013, vol. 9, no. 1, p. 85, 2013. 
[10] Marimin and N. Maghfiroh, "Aplikasi Teknik Pengambilan Keputusan dalam Manajemen Rantai Pasok.” 2011.

[11] R. Evival, "Perkebunan Tebu," 2018.

[12] Menteri Perindustrian dan Perdagangan Republik Indonesia, "Kepmenperindag_643_2002.pdf." 